\title{
PROSES PEMBENTUKAN KOSAKATA DAN FUNGSI BAHASA KELOMPOK GAY
}

\author{
Ahmad Wahyudin \\ Fakultas Bahasa dan Seni Universitas Negeri Yogyakarta \\ e-mail: wahyudinahmad@yahoo.co.id
}

\begin{abstract}
This study aims to describe vocabulary formations and language functions in a gay community. The object was the language employed by such a community. The data were collected through listening, recording, and noting and were analyzed by means of the qualitative descriptive technique. The data trustworthiness was enhanced by careful observations and triangulation (data sources, relevant theories, and other observers). The findings are as follows. First, the vocabulary formations include (a) form addition, (b) form substitution, (c) utilization of short forms (abbreviations and acronyms), and (d) utilization of puns. Second, language in the gay community has four functions, i.e.: (a) emotive function, (b) referential function, (c) phatic function, and (d) conative function.
\end{abstract}

Keywords: vocabulary formation, language function, gay community

\section{PENDAHULUAN}

Sosiolinguistik

memandang

bahwa bahasa tidak dilihat sebagai bahasa, melainkan dilihat atau didekati sebagai sarana interaksi atau komunikasi di dalam sebuah masyarakat. Sosioliguistik hadir dari adanya asumsi keterkaitan bahasa dengan faktor-faktor kemasyarakatan sebagai dampak dari keadaan komunitasnya yang tidak homogen (Wardhaugh, 1990, Holmes, 1995). Sosiolinguistik memandang bahasa sebagai tingkah laku sosial yang dipakai dalam komunikasi, dan bahasa merupakan identitas penutur, baik secara individu ataupun kelompok. Oleh karena itu, segala sesuatu yang dilakukan oleh manusia dalam bertutur akan selalu dipengaruhi oleh situasi dan kondisi di sekitarnya. Hal ini juga dijelaskan oleh Fishman (dalam Wijana \& Muhammad Rohmadi, 2006: 7) yang menyatakan "who speaks what language to whom and when." Dengan demikian, sosiolinguistik membahas masalahmasalah kebahasaan yang dihubungan dengan faktor-faktor sosial, situasional, dan budaya. Dengan adanya berbagai macam faktor tersebut, manusia dengan segala kreatifitasnya mampu meciptakan segala sesuatu, termasuk menciptakan istilah-istilah baru dalam bahasa. Salah satu dari faktor-faktor inilah yang menyebabkan munculnya variasi dan ragam bahasa dalam masyarakat tutur.

Variasi bahasa meliputi variasi kronologis, variasi geografis, variasi sosial, variasi fungsional, variasi gaya, variasi kultural, dan variasi individual (Soeparno 1993). Kaitannya dengan masyarakat sebagai wadah hidup dan tempat berkembangnya suatu bahasa, variasi sosial merupakan satu di antara variasi bahasa yang terus mengalami perubahan seiring dengan perubahan zaman dikaitkan dengan masyarakat pengguna bahasa dan juga sebagai pencipta bahasa. 
Masyarakat bahasa dapat dikelompokkan menjadi beberapa klasifikasi, yaitu berdasarkan umur, kelas sosial, pekerjaan, dan sebagainya. Variasi bahasa yang berkenaan dengan status, golongan, dan kelas sosial para penuturnya disebut sosiolek. Tiap-tiap kelompok ini biasanya berusaha untuk memunculkan satu bahasa tersendiri dengan tujuan-tujuan tertentu. Ada di antara mereka yang menciptakan suatu bahasa demi mewujudkan suatu keakraban dalam komunitasnya, untuk menunjukkan identitas mereka, atau agar orang lain tidak dapat mengerti bahasa mereka. Selanjutnya, muncul beragam bahasa yang hanya diketahui oleh golongan atau kelas sosial tertentu yang sering disebut slang. Chaer (1995) menyatakan bahwa slang adalah variasi sosial bersifat khusus dan rahasia. Artinya, variasi ini digunakan oleh kalangan tertentu yang sangat terbatas, dan tidak boleh diketahui oleh kalangan di luar kelompok itu. Kosakata dalam slang itu berubah-ubah dan bersifat temporal. Faktor yang sering mempengaruhi perubahan kosakata ini adalah kerahasiaan. Slang sering juga disebut bahasa prokem. Pai dan Gaynor (dalam Alwasilah, 1985: 56) mengemukakan definisi slang yaitu:

a style of language in faithly common use, produced by popular adaption and extention of the meaning of existing words and by coining new words with diregrad for scholastic standard and linguistic principles of the formations of word; generally peculiar to certain classes and social or age groups.

Lebih lanjut Hartan dan Stork (dalam Alwasilah, 1985: 57) juga mendefinisikan slang sebagai berikut. a variety of speech characterized by newly coined and rapidly changing vocabulary, used by young and professional groups for "in-group" communication and thus tending to provent understanding by the rest of the speech community.

Berdasarkan beberapa pengertian tentang slang di atas, dapat diketahui bahwa slang adalah salah satu bentuk kebahasaan yang mempunyai ciri-ciri bersifat rahasia, kosakata berubah-ubah, dan digunakan oleh kalangan tertentu. Penggunaan slang adalah memperkenalkan kata-kata baru, memperkaya kosakata bahasa dengan mengkomunikasikan kata-kata lama dengan makna baru. Slang mengacu pada kosakata khusus yang tidak diketahui atau dimengerti orang banyak. Dapat dikatakan bahwa slang adalah ragam bahasa tidak resmi yang dipakai oleh kaum remaja atau kelompok-kelompok sosial tertentu untuk komunikasi intern, sebagai usaha supaya orang-orang di kelompok lain tidak mengerti. Bahasa tersebut berupa kosakata yang serba baru dan berubahubah, misalnya, bahasa prokem di kalangan remaja (Kridalaksana, 1982).

Hal inilah yang dilakukan oleh "Boy" (nama samaran) yang seorang gay beserta komunitasnya. Di dalam komunitasnya, Boy dan teman-temannya selalu menggunakan kata-kata khusus yang mungkin "aneh" jika didengar oleh masyarakat umum.

Dalam sebuah komunikasi, hal yang penting diperhatikan adalah pemahaman antara penutur dan mitra tutur. Komunikasi tidak akan berjalan lancar apabila tidak ada pemahaman antara penutur dan mitra tutur. Misalnya, komunikasi yang terjadi di antara kelompok gay dengan masyarakat pada umumnya menjadi tidak lancar karena kelompok gay menggunakan kata kucing untuk menyebut 'cowok bayaran', sedangkan masyarakat pada umumnya kata kucing untuk menyebut jenis hewan mirip seperti harimau. Penggunaan 
bahasa oleh kaum gay sepertinya memang memiliki fungsi khusus, mereka ingin menunjukkan identitas kelompok mereka kepada masyarakat yang pada dasarnya masih kurang menerima keberadaan mereka sepenuhnya.

Pada tahun 1999, Debby Sahertian menciptakan Kamus Bahasa Gaul. Kamus tersebut berisi istilah-istilah dalam bahasa yang digunakan di kalangan homoseksua, baik gay maupun lesbian. Hal ini membuktikan pula bahwa dalam suatu komunitas masyarakat tertentu memang memerlukan bahasa tertentu demi terciptanya keakraban atau dengan alasan dan tujuan tertentu. Bahasa yang muncul dikalangan homoseksual tersebut disebut sebagai bahasa gaul yang merupakan wujud dari variasi sosial. Bahasa gaul di kalangan homoseksual tersebut bersifat khusus, rahasia, dan hanya digunakan pada kalangan mereka saja.

Pada awalnya, bahasa gaul yang digunakan di kalangan homoseksual memiliki pedoman-pedoman tertentu, misalnya penggantian suku kata terakhir dengan se (Sahertian, 2000), misalnya untuk kata genit maka di ucapkan gense. Namun, pedoman tersebut nampaknya selalu mengalami perubahan, misalnya setelah mengganti suku kata terakhir dengan se mereka menyisipkan bentuk in di antara konsonan dan vokal tiap suku kata, seperti kata banci menjadi binancini, kata gay menjadi ginay. Pedoman-pedoman tersebut pada akhirnya tidak digunakan lagi. Pada saat sekarang ini, kelompok pengguna bahasa tersebut nampaknya tidak memiliki pedoman khusus untuk menciptakan kata-kata tersebut. Mereka cenderung berpedoman pada kesepakatan masyarakat pengguna bahasa sesuai dengan sifat bahasa yang arbiter dan konvensional. Oleh karena itu, kiranya perlu diketahui bagaimana proses atau pola pembentukan kosakata yang digu- nakan oleh kelompok gay pada saat ini dan bahasa yang mereka gunakan memiliki fungsi-fungsi apa saja.

\section{METODE}

Desain penelitian ini adalah penelitian deskriptif kualitatif. Pada penelitian ini, peneliti mencermati dan menyajikan gambaran mengenai gejala yang diteliti, dari data tentang bahasa gay yang ada kemudian dianalisis pembentukan kosakata dan fungsi bahasa yang digunakan.

Subjek penelitian ini adalah "Boy" (nama samaran) dan teman-temannya yang juga seorang gay. Subjek penelitian ditentukan setelah peneliti memasuki setting penelitian dengan menggunakan teknik purpose sampling, yaitu peneliti mempertimbangkan berbagai hal yang berkaitan dengan keperluan (Sudaryanto, 1999). Artinya, dalam hal ini peneliti akan meneliti bahasa gay yang digunakan oleh Boy dan teman-temannya dalam kehidupan sehari-hari. Objek penelitian ini adalah bahasa gay yang digunakan oleh Boy dan teman-temannya dalam komunitasnya. Tentunya, bahasa yang digunakan oleh Boy dan teman-temanya berbeda dengan bahasa yang digunakan oleh masyarakat umum. Objek penelitian ini terfokus pada: (1) proses pembentukan kosa kata bahasa gay, dan (2) fungsi bahasa gay yang mereka gunakan.

Pengambilan data dilakukan secara bertahap dengan memperhitungkan waktu dan situasi. Waktu pengambilan data berlangsung mulai tanggal 2-7 Januari 2008. Tempat penelitian ini yaitu di Yogyakarta dengan mengambil tempat-tempat yang digunakan oleh Boy dan teman-temanya berkumpul, seperti di kos Boy, kos peneliti, dan warung makan tempat mereka berkumpul.

Kaitannya dengan pengumpulan data yaitu data berupa data lisan yang diperoleh dengan cara menyadap 
tuturan yang digunakan oleh Boy dan teman-temannya. Tahap ini digunakan sebagai teknik dasar, dan teknik lanjut dipakai teknik Simak Libat Cakap (SLC) (Sudaryanto, 2001). Dalam teknik ini, peneliti melakukan partisispasi langsung dalam pembicaraan yang terjadi antara Boy dan teman-temannya. Dengan demikian, hal-hal yang dilakukan oleh penelitiadalah:(1) peneliti langsung terjun ke lapangan, (2) peneliti ikut serta aktif dalam percakapan dengan Boy dan teman-temannya, dan (3) peneliti berperan serta dalam kegiatan-kegiatan tertentu yang ada dalam komunitas gay. Hal itu akan membuat hubungan antara peneliti dan yang diteliti seperti dalam suasana biasa, wajar, pertanyaan dan jawaban berjalan seperti pembicaraan biasa dalam kehidupan sehari-hari.

Untuk mendapatkan data yang lebih valid sebagai lanjutan dilakukan pencatatan dan perekaman dengan menggunakan tape recorder. Hal ini dilakukan karena keterbatasan peneliti dalam mengingat. Dengan mencatat dan merekam, diharapkan diperoleh data yang lengkap. Kemudian, setelah data terkumpul dilakukan pencatatan yang dituangkan dalam catatan lapangan.

Instrumen utama dalam penelitian ini adalah peneliti sendiri (human instrument). Dalam hal ini peneliti dituntut memiliki kemampuan dan pengetahuan tentang hal-hal yang berkaitan dengan masalah penelitian, yaitu bahasa gay. Artinya, peneliti harus peka, mampu, logis, dan kritis karena bertindak sebagai perencana, pelaksana, pengambil data, penganalisis, sekaligus sebagai pelapor hasil penelitian.

Pengetahuan dan pengalaman peneliti menjadi kunci pokok dalam keberhasilan penelitian ini. Pada tahap awal pencarian data sampai dengan analisis data peneliti berperan sebagai kunci utama. Selanjutnya, sebagai instrumen tambahan digunakan alat tulis dan tape recorder untuk mencatat dan merekam sumber data lisan.

Analisis data dalam penelitian ini dilakukan dengan menggunakan metode deskriptif kualitatif, yaitu mendeskripsikan segala peristiwa bahasa yang digunakan oleh Boy dan temantemannya. Penelitian ini juga bersifat kualitatif karena data-datanya berupa kata-kata dan tuturan yang digunakan oleh kaum gay.

Untuk memperoleh deskripsi bentuk penggunaan bahasa yang digunakan oleh Boy dan teman-temannya, digunakan metode padan dan metode agih. Metode padan adalah metode analisis bahasa sebagai alat penentunya di luar, terlepas, dan tidak menjadi bagian dari bahasa yang bersangkutan. Kriteria dalam metode padan digunakan dalam penelitian ini meliputi (Sudaryanto, 2001).

Sebagai kriteria digunakan bahasa Indonesia baku untuk mendeskripsikan bahasa gay. Jadi, padan referensial digunakan saat mendeskripsikan arti kata-kata ke dalam bahasa Indonesia baku. Padan pragmatik dengan menggunakan alat penentu maksud tuturan dan struktur digunakan untuk menganalisis struktur dan fungsi bahasa gay.

Metode agih adalah metode analisis bahasa yang alat penentunya merupakan bagian dari bahasa yang bersangkutan itu sendiri. Metode agih sering juga disebut sebagai metode distribusional (Sudaryanto, 2001). Penggunaan metode agih dalam penelitian ini yaitu digunakan untuk proses pembentukan kosakata bahasa gay.

Pemeriksaan keabsahan data dalam penelitian ini dilakukan dengan (1) triangulasi, (2) memperpanjang waktu penelitian, (3) ketekunan pengamatan. Triangulasi adalah teknik pemeriksaan keabsahan data yang memanfaatkan sesuatu yang lain di luar data itu untuk keperluan pengecekan 
atau sebagai pembanding terhadap data itu (Moleong, 2004). Teknik trianggulasi dalam penelitian bahasa gay ini antara lain memanfaatkan: 1) sumber data, yaitu dengan jalan pengecekan ulang terhadap data yang berhasil ditemukan untuk memastikan bahwa data yang diperoleh sesuai dengan keaadaan yang sesungguhnya. Artinya, setelah peneliti memperoleh data melalui pengamatan, peneliti mengecek ulang data tersebut dengan sumber data atau dengan melakukan tanya jawab kepada teman Boy yang juga seorang gay. 2) teori yang relevan, yaitu pemanfaatan teori dilakukan dengan jalan pengecekan silang dengan berbagai teori yang relevan dengan bahasa sebagi bahan pembanding. 3) pengamat lainnya, yaitu dengan memanfaatan pengamat lainnya membantu mengurangi kemencengan dalam pengumpulan data. Dalam hal ini, peneliti melakukan tanya jawab kepada yang lebih ahli untuk menyampaikan analisis data dan mengecek kebenaran data dengan teori yang ada.

Dengan memperpanjang waktu penelitian, diharapkan akan memperoleh data yang semaksimal dan seakurat mungkin. Pada saat penelitian, peneliti berada di tempat penelitian tidak hanya sekali saja, tetapi berkalikali sampai peneliti merasa bahwa data yang diperolehnya sudah cukup. Peneliti merasa data yang diperolehnya cukup karena bahasa yang digunakan oleh Boy dan teman-temannya berkisar pada masalah yang sama dan dengan kosa kata yang sama.

Ketekunan pengamatan dilakukan untuk menemukan ciri-ciri dan unsur pendukung yang sangat relevan dengan persoalan, kemudian memusatkan diri pada hal-hal tersebut secara rinci (Moleong, 2000). Ketekunan pengamatan dalam penelitian ini bertujuan untuk memperoleh data yang benar-benar nyata dan menyelidiki halhal yang mungkin terabaikan.

\section{HASIL DAN PEMBAHASAN}

\section{Bahasa Gay}

Bahasa yang digunakan oleh kalangan homoseksual (gay) ini termasuk dalam bentuk slang. Slang juga dipakai oleh kelompok-kelompok sosial dan profesional untuk komunikasi 'intern'. Jadi, penggunaan slang tersebut cenderung untuk tidak diketahui oleh pihak lain dalam masyarakat ujaran. Kaidahkaidah linguistik dalam pembentukan dan penyusunan kata-katanya sering diabaikan. Pada umumnya penggunaan slang terbatas kelompok-kelompok sosial atau kelompok usia tertentu (Alwasilah, 1985).

Sumarto (1993) menjelaskan slang termasuk variasi atau ragam bahasa lisan yang digunakan dan berlaku di suatu daerah tertentu. Slang tersebut dipopulerkan oleh pengarang atau penyair. Slang yang dipopulerkan oleh kalangan remaja dan dikembangkan oleh remaja pula disebut variasi prokem.

Dalam penelitian ini, pembahasan slang ditekankan pada kata, sebab slang merupakan kawasan kosakata yang dapat diciptakan berdasarkan kata-kata yang terdapat dalam bahasa standar. Kata dalam slang memiliki bentuk kata yang berbeda dengan kata bahasa standar. Karena mempunyai bentuk yang berbeda, maka makna dari kata slang ini sulit dimengerti dan dipahami oleh masyarakat secara umum, dan pemakaiannya pun terbatas pada kelompokkelompok tertentu.

Proses pembentukan kata-kata slang mengalami beberapa perubahan, yang menyangkut bidang fonologi, morfologi, dan sintaktik. Jenis perubahan kata yang menyangkut hal di atas, misalnya adalah metatesis dan adaptasi. Metatesis adalah proses pembentukan 
kata yang dilakukan dengan cara merubah letak susunan fonemnya. Penukaran suatu kata dalam suatu bahasa secara umum yang telah disepakati bersama. Penukaran suatu kata tersebut sering dilakukan dengan sengaja untuk permainan untuk merahasiakan kata-kata tersebut agar orang lain tidak mengerti. Hal ini sering dilakukan oleh penutur slang. Mereka sering mempermainkan kata-kata standar yang ada, dengan

Tabel 2 Fungsi Bahasa Gay cara membalik maupun menukar letak fonem-fonemnya, sedangkan adaptasi yaitu proses perubahan kata yang terjadi karena adanya penyesuaian yang menyangkut sistem bunyi.

Hasil penelitian bahasa gay ini meliputi: (1) proses pembentukan kosa kata bahasa gay, dan (2) fungsi bahasa gay. Hasil penelitian akan di paparkan dalam tabel 1 dan 2.

\begin{tabular}{|c|c|c|}
\hline Fungsi Bahasa & Contoh Tuturan & Arti \\
\hline Emotif & $\begin{array}{l}\text { "Sebel deh adek. Di kos } \\
\text { adek adinda héntong lo } \\
\text { bow.". } \\
\text { "Beneran. Sutra seminggu } \\
\text { ini adek tinte bisa tidore. } \\
\text { Adek takara benye. Malam } \\
\text { indang adek tidore di tempat } \\
\text { kaka..". }\end{array}$ & $\begin{array}{l}\text { "Sebel deh adik. Di kos adik } \\
\text { ada hantu lo". } \\
\text { "Benar. Sudah seminggu ini } \\
\text { adik tidak bisa tidur. Adik } \\
\text { takut sekali. Malam ini adik } \\
\text { tidur di tempat kaka. }\end{array}$ \\
\hline Referensial & $\begin{array}{l}\text { "Dek, es tehnya kurang } \\
\text { manila ya?" } \\
\text { "Gembala benye tuh pere" }\end{array}$ & $\begin{array}{l}\text { "Dik, es tehnya kurang } \\
\text { manis ya?" } \\
\text { "Gemuk sekali tuh } \\
\text { perempuan" }\end{array}$ \\
\hline Fatik & $\begin{array}{l}\text { "Boy, mawar mina apa?" } \\
\text { "Mawar mékong di mandra } \\
\text { bo". }\end{array}$ & $\begin{array}{l}\text { "Boy, mau minum apa?" } \\
\text { "Mau makan di mana? }\end{array}$ \\
\hline Konatif & $\begin{array}{l}\text { "Dek, tolong tuti pintunya } \\
\text { dikit". } \\
\text { "Ya sutra, kaka jadi takara. } \\
\text { Malam indang adek tidore di } \\
\text { tempat kaka. Kalo sutra } \\
\text { ngatinem tidore di sindang } \\
\text { dulu aja. Kaka mawar } \\
\text { ngopy CD dulu." }\end{array}$ & $\begin{array}{l}\text { "Dek, tolong tutup } \\
\text { pintunya dikit" } \\
\text { "Ya sudah, kakak jadi takut. } \\
\text { Malam ini adik tidur } \\
\text { ditempat kakak. Kalau } \\
\text { sudah ngantuk tidur di sini } \\
\text { dulu saja. Kakak mau copy } \\
\text { CD dulu }\end{array}$ \\
\hline
\end{tabular}




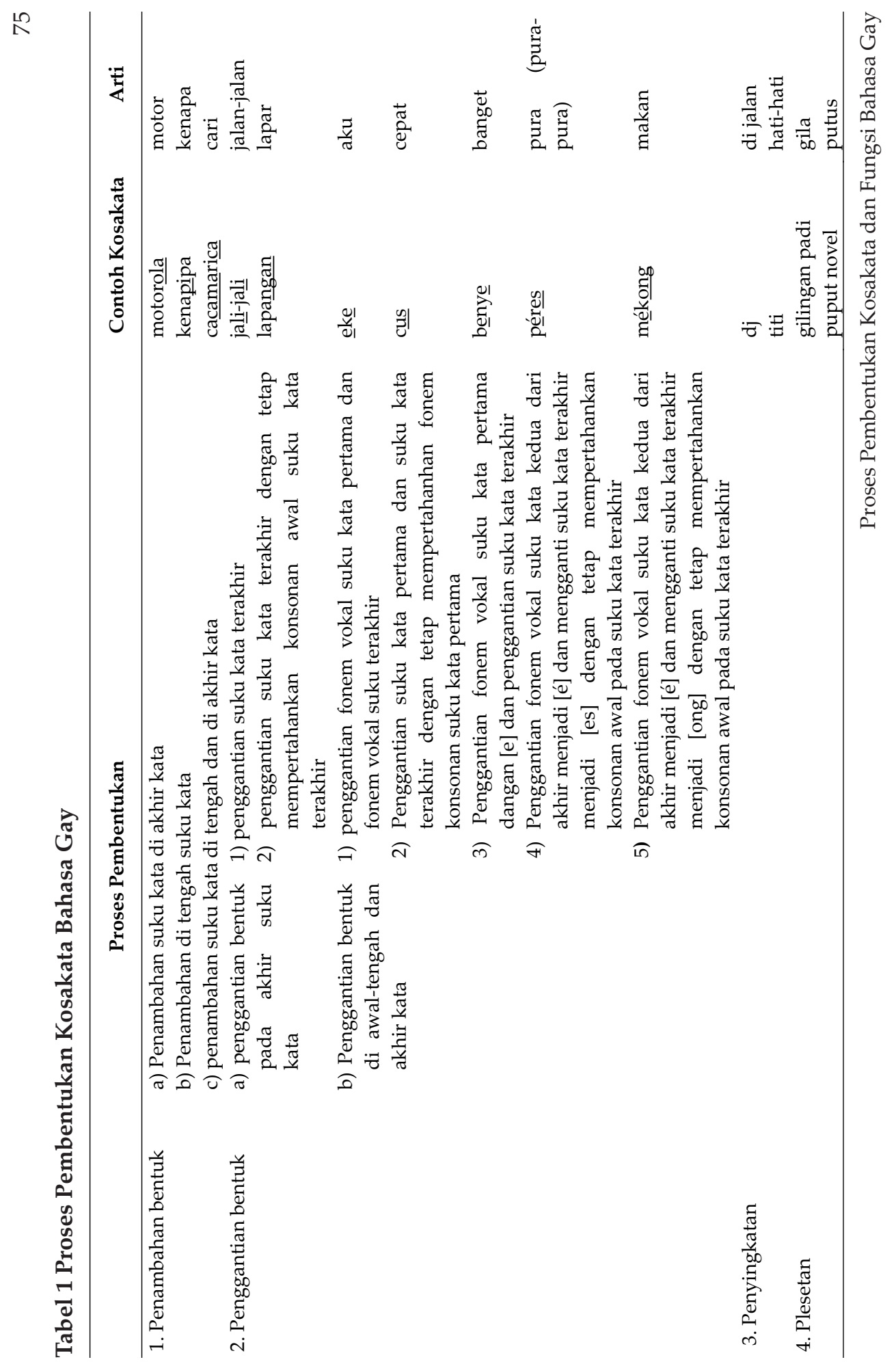




\section{Proses Pembentukan Kosakata Bahasa Gay}

Pembentukkan bahasa gay melalui penambahan bentuk meliputi: (a) penambahan suku kata di akhir kata, (b) penambahan suku kata di tengah, dan (c) penambahan suku kata di tengah dan di akhir kata. Penambahan suku kata di akhir kata pada bahasa gay dapat dilihat pada contoh berikut ini.

(1) "Eke mawar tebar pesona, sekalian cacamarica lékong, sopose tahu dapat bélendong kayangan, cucok lagi". (051)

(2) "Adek pake motorola kaka ya". (042)

Pada tuturan (1) terdapat kata $k a$ yangan yang berasal dari kata kaya, ka-ya, ka-ya-ngan. Perubahan kata kaya menjadi kayangan dengan cara menambah suku kata [ngan] setelah kata kaya. Pada tuturan (2) terdapat kata motorola yang berasal dari kata motor; mo-tor; mo-tor-ola. Kata motor berubah menjadi motorola dengan cara menambah suku kata [ola] setelah kata motor.

Penambahan di tengah suku kata seperti pada tuturan:

(3) "Kenapipa? Adek peres ya? Jéngong bikin kaka takara."(019).

Pada tuturan (3) di atas terdapat kata kenapipa yang berasal dari kata kenapa; ke-na-pa; ke-na-pi-pa. Perubahan kata kenapa menjadi kenapipa yaitu dengan menambahkan [pi] setelah suku kata kedua.

Penambahan suku kata di tengah dan di akhir kata ini dapat dilihat pada contoh berikut ini.

(4) "Eke mawar tebar pesona, sekalian cacamarica lékong, sopose tahu dapat bélendong kayangan, cucok lagi". (051)

Pada tuturan (4) di atas terjadi perubahan kata cari menjadi cacamarica; ca-ri; ca-ca-ma-ri-ca. Perubahan kata cari menjadi cacamarica yaitu dengan menambahkan [ca] dan [ma] setelah suku kata pertama dan menambahkan [ca] di akhir kata.

Selanjutnya, pembentukan bahasa gay melalui penggantian bentuk dilakukan dengan cara: (a) penggantian bentuk pada akhir suku kata, dan (b) penggantian bentuk di awal-tengah dan di akhir kata.

Penggantian bentuk pada akhir suku kata terdiri dari dua tipe, yaitu: (i) penggantian suku kata terakhir dan (ii) penggantian suku kata terakhir dengan tetap mempertahankan konsonan awal suku kata terakhir.

Penggantian bentuk pada akhir suku kata yang berupa penggantian suku kata terakhir dapat dilihat pada contoh berikut ini.

(5) "Begindang ceritanya. Tadinya temen adek yang dihantui. Malem itu kan kita nonton TV di kamar adek, nah adek ketiduran, nah temen adek polda ke kamarnya. Trus paginya diana cerita kalo semalam diana ngéletong adek jali-jali di depan kamarnya, tapi kan adek waktu itu tidore sampe pagi. Habsah itu temenku yang satu lagi ngéletong héntong di kamar mandi. Héntongnya item, gedong, matanya merah. Terus besoknya temen adek yang di kamar bawah juga ngéletong. Pokoknya seminggu itu kita diteror terus". (021)

(6) "Nyebong di ala-ala yuk, sekalian nyari lékong". (031)

(7) "Ya lumajang". (006)

Pada tuturan (5) di atas terdapat kata jali-jali yang berasal dari kata jalan-jalan; ja-lan-ja-lan; ja-li - ja-lí. Perubahan kata jalan-jalan menjadi jali-jali dengan mengganti suku kata terakhir [lan] menjadi [li]. Perubahan kata alunalun menjadi ala-ala pada tuturan (6) di atas yaitu dengan cara mengganti suku kata terakhir [lun] menjadi [la]; $a$-lun - $a$ - 
lun; a-la $-a$-la . Perubahan kata lumayan menjadi lumajang pada tuturan (7) di atas yaitu dengan cara mengganti suku kata terakhir [yang] menjadi [jang]; $l u$ ma-yan; lu-ma-jang

Penggantian bentuk pada akhir suku kata yang berupa penggantian suku kata terakhir dengan tetap mempertahankan konsonan awal suku kata terakhir dapat dilihat pada contoh berikut ini. Perhatikan contoh berikut.

(8) "Lapangan ya". (009)

(9) "Tadi belalang di mandra?". (012)

(10) "Gembala benye tuh pere". (016)

(11) "Sutralah. Habsah mékong mawar jali-jali ke mandra bo?" (035)

Pada tuturan (8) terdapat kata lapangan yang berasal dari kata lapar; la-par; la-pa-ngan. Perubahan kata lapar menjadi lapangan dengan cara mengganti suku kata terakhir [par] dengan tetap mempertahankan konsonan awal pada suku kata terakhir yaitu [p], sehingga [par] menjadi [pangan]. Pada tuturan (9) terdapat kata belalang yang berasal dari kata beli; be-li; be-la-lang. Perubahan kata beli menjadi belalang dengan cara mengganti suku kata terakhir pada kata dasar dengan tetap mempertahankan konsonan pada suku kata terakhir yaitu [1], sehingga [la] menjadi [lalang]. Pada tuturan (10) terdapat kata gembala yang berasal dari kata gemu; ge-muk; gem- $\underline{b a}-$ la. Perubahan kata gemuk menjadi gembala dengan cara mengganti suku kata terakhir pada kata dasar dengan tetap mempertahankan konsonan pada suku kata terakhir yaitu [m], sehingga [muk] menjadi [bala]. Adapun konsonan awal pada suku kata terakhir [m] melekat pada suku pertama, sehingga suku kata pertama tidak menjadi [ge], tetapi menjadi [gem]. Pada tuturan (11) terdapat kata habsah yang berasal dari kata habis; ha-bis; hab-sah. Perubahan kata habis menjadi habsah dengan cara mengganti suku kata terakhir pada kata dasar juga dengan tetap mempertahankan konsonan pada suku kata terakhir yaitu [b], sehingga [bis] menjadi [sah]. Adapun konsonan awal pada suku kata terakhir [b] melekat pada suku pertama, sehingga suku kata pertama tidak menjadi [ha], tetapi menjadi [hab].

Penggantian bentuk di tengah dan di akhir kata dengan cara: (i) penggantian fonem vokal suku kata pertama dan fonem vokal suku terakhir, (ii) Penggantian suku kata pertama dan suku kata terakhir dengan tetap mempertahanhan fonem konsonan suku kata pertama. (iii) 3) Penggantian fonem vokal suku kata pertama dangan [e] dan penggantian suku kata terakhir, (iv) Penggantian fonem vokal suku kata kedua dari akhir menjadi [é] dan mengganti suku kata terakhir menjadi [es] dengan tetap mempertahankan konsonan awal pada suku kata terakhir, dan (v) Penggantian fonem vokal suku kata kedua dari akhir menjadi [é] dan mengganti suku kata terakhir menjadi [ong] dengan tetap mempertahankan konsonan awal pada suku kata terakhir.

Penggantian fonem vokal suku kata pertama dan fonem vokal suku terakhir dapat dilihat pada contoh di bawah ini.

(12) "Yang penting mursida...endes. Duta eke pas-pasan". (001)

Pada tuturan (12) di atas terdapat kata eke yang berasal dari kata $a k u ; a-k u$; $\underline{e}$-ke. Perubahan kata aku menjadi eke dengan cara mengganti suku kata pertama pada fonem vokal [a] dengan [e] dan mengganti fonem vokal suku kata terakhir [u] dengan [e].

Penggantian suku kata pertama dan suku kata terakhir dengan tetap mempertahanhan fonem konsonan suku kata pertama dapat dilihat pada contoh berikut ini.

(13) “Cus ah..". (038) 
Pada tuturan (13) di atas terdapat kata cus yang berasal dari kata cepat; cepat; cus. Perubahan kata cepat menjadi cus dengan cara mengganti suku kata pertama [ce] dengan tetap mempertahankan fonem konsonana [c] dan mengganti suku kata terakhir [pat] dengan [us] sehingga menjadi [cus].

Penggantian fonem vokal suku kata pertama dangan [e] dan penggantian suku kata terakhir adalah sebagai berikut.

(14) "Em, udah gembala sissy benye lagi". (017)

Pada tuturan (14) di atas terdapat kata benye yang berasal dari kata bange; ba-nget; be-nye. Perubahan kata banget menjadi benye dengan cara mengganti suku kata pertama pada fonem vokal [a] dengan [e] dan mengganti suku kata terakhir [nget] dengan [nye].

Penggantian fonem vokal suku kata kedua dari akhir menjadi [é] dan mengganti suku kata terakhir menjadi [es] dengan tetap mempertahankan konsonan awal pada suku kata terakhir adalah sebagai berikut.

(15) “Kenapipa? Adek peres ya? Jéngong bikin kaka takara". (019).

Pada tuturan (15) di atas terdapat kata peres yang berasal dari kata pura; (pura-pura); pu-ra; pé-res. Pada suku pertama [pu] terjadi penggantian fonem vokal [u] menjadi [é] dan penggantian suku kata terakhir dengan mempertahankan konsonan awal, yaitu pada suku kata terakhir [r] yang semula [ra] menjadi [res].

Penggantian fonem vokal suku kata kedua dari akhir menjadi [é] dan mengganti suku kata terakhir menjadi [ong] dengan tetap mempertahankan konsonan awal pada suku kata terakhir dapat dilihat pada contoh di bawah ini.

(16) “Ram, mawar mékong apa?". (002)

(17) “Em, gula lagi méhong kali”. (011)

(18) "Sebel deh adek. Di kos adek adinda héntong lo bow.." (18)

(19) "Terus métong, jadi héntong?" (025)

(20) "Ko sek yo, eke mawar kencang sama déndong sek" (035)

(21) "Pokoknya semuanya grétong, eke yang béyong deh" (050)

Pada tuturan (16) di atas kata mékong yang berasal dari kata makan; makan; mé-kong. Pada suku pertama [ma], terjadi penggantian vokal [a] menjadi [é] dan penggantian suku kata terakhir dengan tetap mempertahankan konsonan awal pada suku kata terakhir [k], sehingga [kan] menjadi [kong]. Pada tuturan (17) di atas kata méhong yang berasal dari kata mahal; ma-hal; mé-hong. Pada suku pertama [ma], terjadi penggantian vokal [a] menjadi [é] dan penggantian suku kata terakhir dengan tetap mempertahankan konsonan awal pada suku kata terakhir [h], sehingga [hal] menjadi [hong]. Pada tuturan (18) di atas kata héntong yang berasal dari kata hantu; han-tu; hén-tong. Pada suku pertama [han], terjadi penggantian vokal [a] menjadi [é] dan penggantian suku kata terakhir dengan tetap mempertahankan konsonan awal pada suku kata terakhir [t], sehingga [to] menjadi [tong]. Pada tuturan (19) di atas kata métong yang berasal dari kata mat; ma-ti; mé-tong. Pada suku pertama [ma], terjadi penggantian vokal [a] menjadi [é] dan penggantian suku kata terakhir dengan tetap mempertahankan konsonan awal pada suku kata terakhir [t], sehingga [ti] menjadi [tong]. Pada tuturan (20) di atas kata déndong yang berasal dari kata dandan; dan-dan; dén-dong. Pada suku pertama [dan], terjadi penggantian vokal [a] menjadi [é] dan penggantian suku kata terakhir dengan tetap mempertahankan 
konsonan awal pada suku kata terakhir [d], sehingga [dan] menjadi [dong]. Pada tuturan (21) di atas kata grétong yang berasal dari kata gratis; gra-tis; gré-tong dan béyong; ba-yar; bé-yong yang berasal dari kata bayar. Pada kata gratis, suku pertama [gra], terjadi penggantian vokal [a] menjadi [é] dan penggantian suku kata terakhir dengan tetap mempertahankan konsonan awal pada suku kata terakhir [t], sehingga [tis] menjadi [tong]. Begitu juka pada kata bayar, suku pertama [ba], terjadi penggantian vokal [a] menjadi [é] dan penggantian suku kata terakhir dengan tetap mempertahankan konsonan awal pada suku kata terakhir [y], sehingga [yar] menjadi [yong].

Pembentukan kosakata bahasa gay dengan penyingkatan terbagi menjadi dua, yaitu dalam bentuk singkatan dan dalam bentuk akronim. Pembentukan kosa kata bahasa gay dalam bentuk singkatan dari dua kata diambil satu huruf tiap awal kata dan dieja huruf demi huruf.

Contoh:

(22) “Tinte nyonya. Titi DJ ya”. (045)

Pada tuturan (22) di atas terdapat kata $D J$ yang berasal dari kata di jalan. Perubahan kata di jalan menjadi DJ dengan cara mengambil satu huruf awal kata dan dieja huruf demi huruf.

Selain dengan menggunkan singkatan, pembentukan kosakata bahasa gay juga dengan menggunakan akronim, yaitu akronim dibentuk dari dua suku kata akhir dari satu kata ulang.

(23) “Tinte nyonya. Titi DJ ya". (045)

Pada tuturan (23) di atas terdapat kata titi yang berasal dari kata hati-hati; ha- $\underline{t} \underline{i}-h a-\underline{t} \underline{i} ; \underline{t} \underline{-}-\underline{t i}$. Perubahan kata hatihati menjadi titi dengan cara mengambil dua suku kata terakhir dari satu kata ulang.

Pembentukan kosakata bahasa gay dengan plesetan sebagaimana tampak pada contoh berikut ini.
(24) "Ih gilingan padi. Tinte la ya. Ya sutra, eke sutra lapangan benye" (045)

(25) "Aduh...gimandra Boy? eke puput novel samarinda pancaroba eke". (046).

(26) "Tinte. Rexona mulu, nanti sakara $10^{\prime \prime} .(024)$

Pada tuturan (24) terdapat kata gilingan padi yang berasal dari kata gila. Kata gila diplesetkan menjadi gilingan padi. Pada tuturan (25) terdapat kata puput novel yang berasal dari kata putus. Kata putus diplesetkan menjadi nama seorang artis, yaitu puput novel. Pada tuturan (26) juga terdapat kata rexona yang berasal dari kata rokok. Kata rexona bagi masyarakat umum biasanya digunakan untuk menyebut jenis minyak wangi, akan tetapi di dalam bahasa gay kata itu digunakan untuk menyebut rokok.

\section{Fungsi Bahasa Gay}

Secara umum bahasa gay berfungsi sebagai sarana komunikasi. Halliday (dalam Brown, 2000) membagi fungsi bahasa menjadi tujuh fungsi, yaitu fungsi instrumental, regulasi, representasional, interaksional, personal, heuristik, dan imajinatif. Secara lebih rinci bahasa gay memiliki fungsi-fungsi sebagai berikut.

Fungsi emotif bertujuan untuk mengungkapkan keadaan penutur, misalnya untuk mengungkapkan emosi dan perasaannya seperti perasaan gembira, sedih, takut, terkejut, dan sebagainya. Bentuk-bentuk tuturan bahasa gay yang mengandung fungsi emotif dapat dilihat pada contoh di bawah ini.

(27) "Sebel deh adek. Di kos adek adinda héntong lo bow.".(018)

(28) "Beneran. Sutra seminggu ini adek tinte bisa tidore. Adek takara benye. Malam indang adek tidore di tempat kaka..".(020) 
(29) "Aduh...gimandra Boy? eke puput novel samarinda pancaroba eke". (046).

Tuturan (27) dan (28) menyatakan kekesalan dan ketakutan teman Boy karena di kamarnya ada hantu, dan sudah hampir seminggu ia tidak bisa tidur karena ketakutan. Tuturan (29) menyatakan kebingungan teman Boy karena ia baru saja putus dari pacarnya. Tuturantuturan tersebut digunakan oleh penutur untuk mengungkapkan semua perasaan yang ada pada dirinya waktu itu.

Fungsi referensial bahasa gay bertujuan untuk menyampaikan suatu topik atau masalah kepada orang lain. Jadi, bahasa gay akan memiliki fungsi referensial apabila tumpuan pembicaraannya ada pada konteks. Misalnya:

(30) "Dek, es tehnya kurang manila ya?" (010)

(31) "Gembala benye tuh pere" (016).

(32) "Eh tinte, eke masih brondong benye, masih laksa". (037)

Tuturan di atas meletakkan tumpuan pembicaraan pada konteks pembicaraan. Tuturan (30) menyatakan es teh yang kurang manis, tuturan (31) menunjukkan penampilan seseorang yang gemuk sekali, dan tuturan (32) menyatakan keadaan penutur yang masih muda sekali dan masih laku.

Fungsi fatik merupakan fungsi bahasa yang bertujuan untuk mengadakan kontak dengan orang lain, dengan kata lain tumpuan pembicaraannya pada kontak. Ujaran-ujaran bahasa gay yang memiliki fungsi fatik biasanya digunakan sebagai pembuka percakapan, pembentuk dan pemelihara hubungan atau kontak antara penutur dan mitra tutur. Penggunaan bahasa gay yang berfungsi fatik dapat dilihat pada contoh berikut ini.

(33) "Boy, mawar mina apa?" (007) (027)

"Mawar mékong di mandra bo".

Tuturan (33) dan (34) di atas di gunakan penutur untuk mengadakan kontak kepadan mitra tuturnya, yaitu dengan menanyakan mau makan apa (33) dan mau makan di mana (34).

Fungsi konatif merupakan fungsi bahasa yang berusaha mengungkap keinginan penutur terhadap lawan tuturnya. Fungsi ini dapat berupa sindiran, perintah, himbauan atau permintaan. Contoh:

(35) "Dek, tolong tuti pintunya dikit". (013)

(36) "Ya sutra, kaka jadi takara. Malam indang adek tidore di tempet kaka. Kalo sutra ngatinem tidore di sindang dulu aja. Kaka mawar ngopy CD dulu." (022)

(37) "Tinte. Rexona mulu, nanti sakara lo".(024)

Tuturan (35) dan (36) memiliki fungsi yang sama, yaitu perintah penutur kepada mitra tutur untuk menutup pintu (35), dan perintah penutur kepada mitra tuturnya untuk tidur di kosnya (36). Sedangkan tuturan (37) adalah berupa larangan penutur kepada mitra tutur agar tidak merokok terus.

\section{SIMPULAN}

Proses pembentukan kosakata yang terjadi pada bahasa gay dapat terjadi dengean beberapa cara, yaitu penambahan bentuk, penggantian bentuk, penyingkatan, dan plesetan, yaitu dengan memlesetkan kosakata dengan menggunakan referen yang lain. Bahasa gay memiliki empat fungsi, yaitu: (1) fungsi emotif, yaitu untuk mengungkapkan perasaan penutur (2) fungsi referensial, yaitu membicarakan dengan topik tertentu (3) fungsi fatik, yaitu untuk mengadakan kontak dengan mitra tutur, dan (4) fungsi konatif, yaitu untuk 
menyampaikan keinginan penutur seperti perintah dan larangan.

\section{UCAPAN TERIMA KASIH}

Artikel ini diangkat dari penelitian mandiri swadana yang dilaksanakan pada tahun 2008. Ucapan terima kasih disampaikan kepada mitra sejawat yang telah membantu kegiatan verifikasi dan triangulasi data dan hasil penelitian.

\section{DAFTAR PUSTAKA}

Alwasilah, C. A. 1985. Sosiologi bahasa. Bandung: Angkasa.

Brown, H.D. 2000. Principles of language learning and teaching. New York: Pearson Education Company.

Chaer, Abdul dan Agustina, Leonie. 1995. Sosiolinguistik perkenalan awal. Jakarta: Rineka Cipta.

Holmes, Janet. 1995. An introduction to socilinguistics. London: Longman Grup Limited.

Kridalaksana, Harimurti. 1982. Fungsi bahasa dan sikap bahasa. Ende Flores: Nusa Indah.

Moleong. L. J. 2004. Metodologi penelitian kualitatif. Bandung: PT Remaja Rosdakarya.
Sahertian, Debby. 2000. Kamus bahasa gaul. Jakarta: Suara Harapan.

Soeparno. 1993. Dasar-dasar linguistik. Yogyakarta: Mitra Gama Widya.

Sudaryanto. 1999. Metodologi penelitian pendidikan bahasa suatu pengantar dan pedoman singkat dan praktis (diktat kuliah). Yogyakarta: FBS UNY.

Sudaryanto. 2001. Metode dan teknik analisis bahasa pengantar penelitian wahana kebudayaan secara linguistis. Yogyakarta: Gadjah Mada University Press.

Sumarto, M. Adi. 1984. Pengantar ilmu bahasa umum. Yogyakarta: Jawa Dharma.

Wardhaugh, Ronald. 1990. An introduction to sociolinguistics. Oxford: Basil Blackwell.

Wijana, I Dewa Putu \& Muhammad Rohmadi. 2006. Sosiolinguistik kajian teori dan analisis. Yogyakarta: Pustaka Pelajar. 
Lampiran 1: Daftar Kosakata Bahasa Gay

\begin{tabular}{|c|c|c|}
\hline No & bahasa gay & arti \\
\hline 1. & adinda & Adik \\
\hline 2. & ajijah & aja/saja \\
\hline 3. & Ala-ala & alun-alun \\
\hline 4. & apose & apa \\
\hline 5. & begindang & Begini \\
\hline 6. & belalang & banget \\
\hline 7. & benye & Banget \\
\hline 8. & béyong & Bayar \\
\hline 9. & bélendong & bule \\
\hline 10. & brondong & Muda \\
\hline 11. & cacamarica & Cari \\
\hline 12. & célenong & Celana \\
\hline 13. & cucok & cukup cakep \\
\hline 14. & Cus & Cepat \\
\hline 15. & diana & Dia \\
\hline 16. & deli & Dalam \\
\hline 17. & duta & duit/uang \\
\hline 18. & Eke & Aku \\
\hline 19. & Em & iya/emang \\
\hline 20. & endes & Enak \\
\hline 21. & gedong & gede/besar \\
\hline 22. & gembala & Gemuk \\
\hline 23. & gilingan padi & Gila \\
\hline 24. & gimandra & gimana/bagaimana \\
\hline 25. & grétong & Gratis \\
\hline 26. & habsah & Habis \\
\hline 27. & héntong & Hantu \\
\hline 28. & hépong & $\mathrm{Hp}$ \\
\hline 29. & ikatan & Ikutan \\
\hline 30. & indang & Ini \\
\hline 31. & Jail-jali & jalan-jalan \\
\hline 32. & jéngong & Jangan \\
\hline 33. & kayangan & Kaya \\
\hline 34. & kenapipa & Kenapa \\
\hline 35. & kencang & Kencing \\
\hline 36. & kucing & cowok bayaran \\
\hline 37. & laksa & Laku \\
\hline 38. & lambreta & Lama \\
\hline 39. & lapangan & Lapar \\
\hline 40. & lékong & Lelaki \\
\hline 41. & lékong ser & lelaki bukan gay \\
\hline 42. & lumajang & Lumayan \\
\hline 43. & mandra & Mana \\
\hline 44. & manila & Manis \\
\hline 45. & mawar & Mau \\
\hline
\end{tabular}


46. méhong

47. mékong

48. mékongan

49. métong

50. mina

51. motorola

52. mursida

53. ngatinem

54. ngéletong

55. nyebong

56. pancaroba

57. pecun

58. pembantaian

59. pere

60. peres

61. polda

62. puput novel

63. omi-omi

64. rexona

65. sapose

66. sakara

67. sandra

68. samarinda

69. sindang

70. sissy

71. sutra

72. sutras

73. takara

74. tidore

75. tinte

76. titi dj

77. Tuir

78. Tuti

79. yey
Mahal

Makan

Makanan

Mati

Minum

Motor

Murah

Ngantuk

ngelihat/melihat

Nongkrong

Pacar

Pelacur

Pembantu

Perempuan

pura-pura

Pulang

Putus

om-om

Rokok

Siapa

Sakit

Sana

Sama

Sini

kemayu/genit

Sudah

Stress

Takut

Tidur

Tidak

hati-hati di jalan

Tua

Tutup

Kamu 